\title{
Wood anatomy of Mollinedia glabra (Spreng.) Perkins (Monimiaceae) in two Restinga Vegetation Formations at Rio das Ostras, RJ, Brazil
}

\author{
FERNANDA DA S. NOVAES ${ }^{1}$, CÁTIA H. CALLADO ${ }^{2}$, \\ MARIA VERÔNICA L. PEREIRA-MOURA ${ }^{1}$ and HELENA R.P. LIMA ${ }^{1}$ \\ ${ }^{1}$ Universidade Federal Rural do Rio de Janeiro, Instituto de Biologia, Departamento de Botânica \\ Rod. BR 465, km 7, Caixa Postal 74582, 23890-000 Seropédica, RJ, Brasil \\ ${ }^{2}$ Universidade do Estado do Rio de Janeiro, Instituto de Biologia Roberto Alcântara Gomes \\ Departamento de Biologia Vegetal, Laboratório de Anatomia Vegetal \\ Rua São Francisco Xavier, 524-PHLC, 20550-013 Rio de Janeiro, RJ, Brasi
}

Manuscript received on November 3, 2009; accepted for publication on July 1, 2010

\begin{abstract}
This paper aimed to characterize the anatomical structure of the wood of specimens of Mollinedia glabra (Spreng.) Perkins growing in two contiguous formations of restinga vegetation at Praia Virgem, in the municipality of Rio das Ostras, RJ. Both the Open Palmae (OPS) and the Sandy Strip Closed Shrub (SSCS) formations are found in coastal regions that receive between 1,100 and $1,300 \mathrm{~mm}$ of rainfall per year. Sapwood samples were collected in both formations. Typical anatomical features for this species include: solitary vessels, radial multiples or clusters elements, that are circular to angular in outline, 5-15 barred scalariform perforation plates, wood parenchyma scanty, septate fiber-tracheids, and wide multiseriate rays with prismatic crystals. Statistical analyses indicated a significant increase in the frequency of vessel elements and an increase in fiber-tracheid diameters in OPS individuals. These characteristics are considered structural adaptations to increased water needs caused by a greater exposure to sunlight. Continuous pruning may be responsible for the tyloses observed in OPS plants. The greater lengths and higher frequencies of the rays in SSCS trees may be due to the greater diameters of their branches. Our results suggest that M. glabra develops structural adaptations to the restinga micro-environmental variations during its development.
\end{abstract}

Key words: Mollinedia glabra, Monimiaceae, restinga, wood anatomy.

\section{INTRODUCTION}

Monimiaceae (sensu stricto) is a Pantropical family comprising 25 to 30 genera and about 200 species. Five genera are cited for Brazil: Grazielanthus Peixoto \& Per-Moura, Hennecartia Poisson; Macropeplus Perkins; Macrotorus Perkins, and Mollinedia Ruiz \& Pav (Peixoto and Pereira-Moura 2008).

The genus Mollinedia has the largest number of described species and is typified by highly branched shrubs or small trees with erect trunks (Peixoto 1979) that normally grow near rivers and streams. The wood

Correspondence to: Helena Regina Pinto Lima

E-mail: helena@ufrrj.br of this taxon is hard, whitish, and easy to work, although it is little harvested commercially (Peixoto et al. 2001). These trees have medicinal uses (Leitão et al. 1999) and some species are used in urban landscaping and to produces barrels and sieves in southern Brazil, they also have an important role in reforestation and in the maintenance of the local fauna (Peixoto et al. 2001). Mollinedia glabra (Spreng.) Perkins is considered a threatened species in Brazil (Ibama 2008), with small populations that occur only in coastal lowlands. The species occurs in two distinct vegetation formations in the restinga region of Praia Virgem, municipality of Rio das Ostras, Rio de Janeiro: Open Palmae Shrub (OPS) and Sandy Strip Closed Shrub (SSCS). 
Most studies concerning this genus in Brazil have focused on their taxonomic (Peixoto et al. 2001, 2002) or phytochemical (Leitão et al. 1999) nature, with only infrequent works concentrating on the anatomical or ecological aspects of this taxon (Barros et al. 1997, Callado et al. 1997). Anatomical studies of wood are considered to be very informative (Metcalfe 1989), mainly when correlated with evolutive and phylogenetic questions, as environmental factors are considered active in defining the structure of the secondary xylem (Aguilar-Rodríguez and Barajas-Morales 2005, Carlquist 2000). Although the first anatomical studies considering ecological aspects of plant populations were first performed in the 1970's (Baas 1973, Carlquist 1975), this type of investigation is still uncommon in the tropics - largely due to the great variety of species and environments found there. In general, researchers that use the anatomical characters of wood in studies of intra-specific variation in ecologically distinct environments have described modifications in the diameter, length, and frequency of the vessel elements, the thickness of the walls and the lengths of the fibers, and the height and width of the rays (Baas et al. 1983, Callado et al. 1997, Wheeler and Baas 1991, Marcati et al. 2001, León 2005, Ribeiro and Barros 2006).

The present work described and compared the wood anatomy of individuals of M. glabra growing in two contiguous vegetation formations under distinct illumination and disturbance regimes in restinga (shoreline) vegetation at Praia Virgem, municipality of Rio das Ostras, Rio de Janeiro, Brazil.

\section{MATERIALS AND METHODS}

The studied plant material was collected in an area of restinga vegetation at Praia Virgem, municipality of Rio das Ostras, Rio de Janeiro, Brazil $\left(22^{\circ} 31^{\prime} \mathrm{S} \times\right.$ $\left.41^{\circ} 56^{\prime} \mathrm{W}\right)$. This coastal restinga area occupies about 20 ha on a narrow strip of sand, circa $1 \mathrm{~km}$ long, along the coast (H. Braga, unpublished data). Two distinct vegetation formations were identified there (Menezes et al. 2005): Open Palmae Shrub (OPS) and Sandy Strip Closed Shrub (SSCS), corresponding to the edge and to the interior of the restinga forest, respectively (Figs. 1a, b). The region receives 1,100 to $1,300 \mathrm{~mm}$ of rainfall annually, and the climate is mesothermic, sub-humid to humid, with only a small water deficit during the year (FIDERJ 1978). The two vegetation formations are separated by circa $200 \mathrm{~m}$ and differ mainly concerning the amount of sunlight that they receive, their exposure to the on-shore winds, and in terms of anthropogenic disturbances, the OPS suffering from frequent pruning.

Samples from three individuals of Mollinedia glabra were obtained in the vegetation formations (Table I). As this species is normally branched near the base, samples of the SSCS individuals were collected from the most developed branches at breast height (1.30 $\mathrm{m}$ above ground level), and from the middle of straight branches of individuals at the OPS site (Table I). The wood samples, as suggested by Coradin and Muñiz (1991), were obtained from the sapwood region, as the heartwood was rather small. Reproductive material was housed at the Herbarium RBR of the Botany Department of the UFRRJ under the number 401054.

\section{TABLE I}

List of individuals sampled in both sites, collection sites, dendrometrics data and record from the wood collection of Instituto de Pesquisas Jardim Botânico Rio de Janeiro (OPS Open Palmae Shrub; SSCS - Sandy Strip Closed Shrub Growing; $\mathrm{H}=$ plant height (m), CSH = circumference at sampling height $(\mathrm{cm}) ; \mathrm{RBw}=$ record of the wood; $\mathrm{SLI}=$ record of the slides).

\begin{tabular}{c|c|c|c|c|c}
\hline Inds & $\begin{array}{c}\text { collection } \\
\text { sites }\end{array}$ & $\begin{array}{c}\mathrm{H} \\
(\mathrm{m})\end{array}$ & $\begin{array}{c}\mathrm{CSH} \\
(\mathrm{cm})\end{array}$ & RBw & SLI \\
\hline 1 & OPS & 0.6 & 7.6 & 8563 & 2250 \\
\hline 2 & OPS & 1.0 & 7.5 & 8564 & 2251 \\
\hline 3 & OPS & 1.8 & 7.8 & 8424 & 2146 \\
\hline 4 & SSCS & 2.5 & $8.1^{*}$ & 8425 & 2147 \\
\hline 5 & SSCS & 3.0 & $7.8^{*}$ & 8566 & 2253 \\
\hline 6 & SSCS & 3.5 & $8.0^{*}$ & 8565 & 2252 \\
\hline
\end{tabular}

$\left(^{*}\right)$ Samples collected at $1.30 \mathrm{~m}$ above ground level.

The wood samples from each of the studied individuals were sectioned along their transversal and longitudinal planes, at an average thickness of $15 \mu \mathrm{m}$. The histological sections were cleared, stained, dehydrated and mounted as permanent slides. The stain that was used was a mixture of $1 \%$ astra blue and safranin (Burguer and Richter 1991). The permanent slides were housed at the Xylothek of the Instituto de Pesquisas Jardim Botânico of Rio de Janeiro (JBRJ) under the 


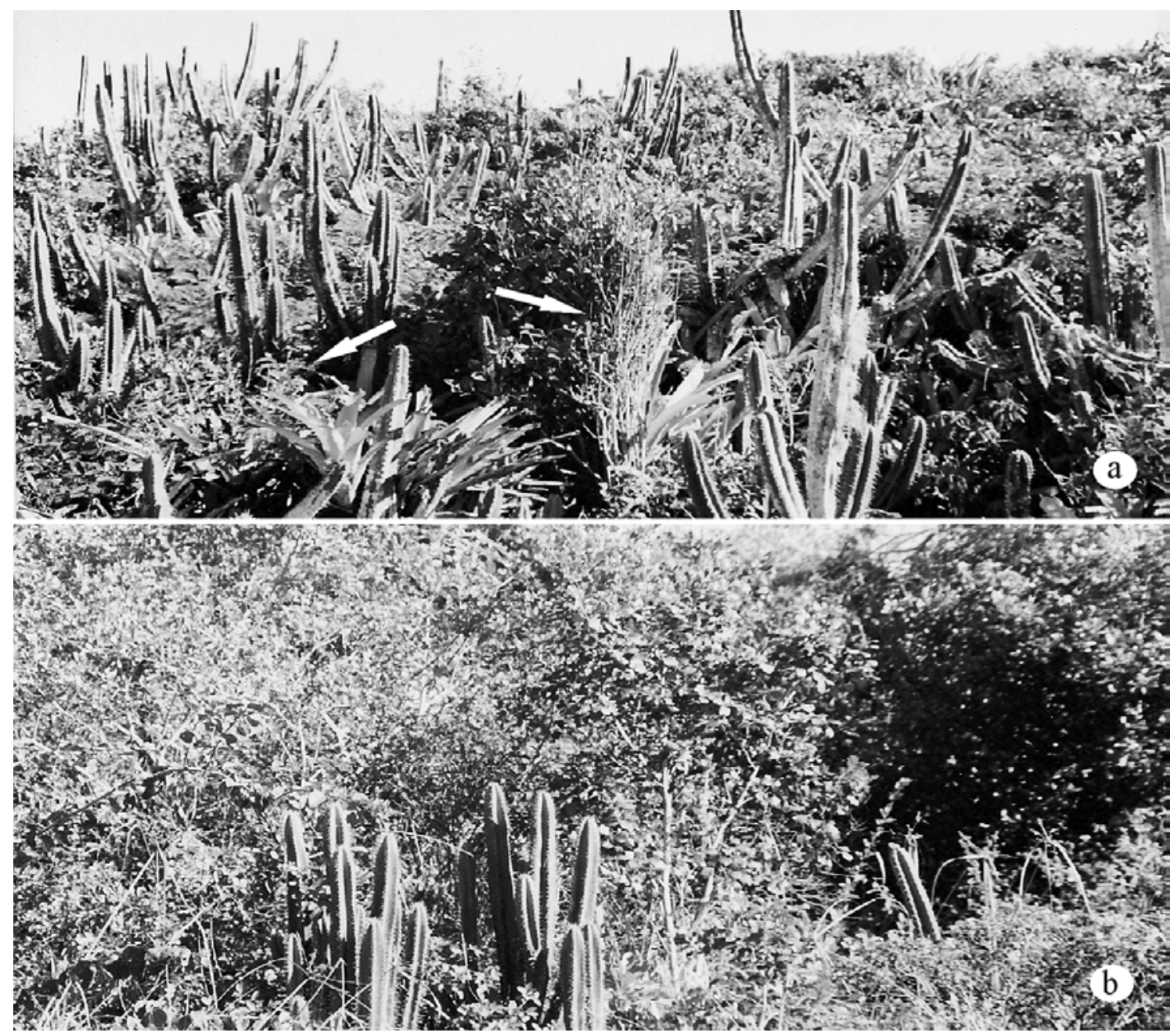

Fig. 1 - a. Aspect of the Open Palmae Shrub (OPS), individuals of Mollinedia glabra (arrows). b. Aspect of the Shrubby Vegetation (SSCS).

registration numbers indicated in Table I. The wood fragments were boiled in 50\% nitric acid to dissociate the cellular elements (modified from Occhioni 1948). The descriptions, counts, and measurements of the cellular elements followed the norms of the IAWA Committee (1989) and Coradin and Muñiz (1991). The numbers of measurements per analyzed individual were: 10 , for frequency and diameter of the vessels elements; 20, for the ray frequencies; and 25 , for other parameters (Table II).

Quantitative data were obtained by measurements and counts of 12 parameters observed in the vessels, fibers, and radial parenchyma in each of the specimens from the two analyzed vegetation formations. The data were first tested for normality using the Lilliefors test (Lilliefors 1967) at an alfa significance level of 0.05 . The data for all of the analyzed parameters were determined to have normal distributions. The Student $t$ test was then used to compare the two means of the independent data, at an alfa significance level of 0.05 , by using the XLStat version 7.5 software package (Table III).

In order to compare environmental effects on anatomical characters associated with water transport, vulnerability, and mesomorphy indices were applied according to Carlquist (1975).

Photomicrographs were taken using an Olympus PM-C35B camera coupled to an Olympus CH30 microscope. 
TABLE II

Mean and Standard Deviation of wood anatomical features of Mollinedia glabra in both plant formations (OPS = Open Palmae Shrub, SSCS = Sandy Strip Closed Shrub).

\begin{tabular}{|c|c|c|c|c|c|}
\hline \multicolumn{2}{|c|}{ Mollinedia glabra } & $\begin{array}{c}\text { OPS } \\
\text { Deviation }\end{array}$ & $\begin{array}{l}\text { Standard } \\
\text { Deviation }\end{array}$ & SSCS & Standard \\
\hline \multicolumn{2}{|l|}{ Growth rings } & distinct & & indistinct & \\
\hline \multicolumn{2}{|l|}{ Porous } & difuse & & difuse & \\
\hline \multicolumn{2}{|c|}{ Vessels frequency $\left(\mathrm{mm}^{2}\right)$} & 78.5 & \pm 20.4 & 57.7 & \pm 18.7 \\
\hline \multicolumn{2}{|c|}{ Vessels lenght $(\mu \mathrm{m})$} & 818.5 & \pm 76.4 & 843.3 & \pm 52.7 \\
\hline \multicolumn{2}{|c|}{ Vessels diameter $(\mu \mathrm{m})$} & 38.6 & \pm 8.0 & 36.3 & \pm 5.1 \\
\hline \multicolumn{2}{|c|}{ Vessels wall thickness $(\mu \mathrm{m})$} & 3.7 & \pm 0.2 & 3.7 & \pm 0.6 \\
\hline $\begin{array}{l}\text { Number of bars } \\
\text { of scalariform }\end{array}$ & Perforation plates & $5-15$ & \pm 0.2 & $7-14$ & \pm 1.1 \\
\hline \multirow{2}{*}{ Vessels } & \multirow{2}{*}{$\begin{array}{l}\text { Radial multiples } \\
\text { Clusters }\end{array}$} & $2-5$ & & $2-4$ & \\
\hline & & $2-6$ & & $2-8$ & \\
\hline \multirow{2}{*}{$\begin{array}{l}\text { Intervessel } \\
\text { pitting }\end{array}$} & \multirow{2}{*}{$\begin{array}{l}\text { Scalariform }(\mu \mathrm{m}) \\
\text { Opposite }(\mu \mathrm{m})\end{array}$} & 15.2 & \pm 2.4 & 13.9 & \pm 2.0 \\
\hline & & 6.5 & \pm 1.1 & 6.4 & \pm 0.5 \\
\hline \multirow{2}{*}{$\begin{array}{l}\text { Vessel-ray } \\
\text { pitting }\end{array}$} & \multirow{2}{*}{$\begin{array}{l}\text { Scalariform }(\mu \mathrm{m}) \\
\text { Opposite }(\mu \mathrm{m})\end{array}$} & 15.4 & \pm 7.1 & 15.7 & \pm 2.7 \\
\hline & & 8.6 & \pm 3.5 & 7.2 & \pm 0.7 \\
\hline \multicolumn{2}{|c|}{ Fibers-tracheids lenght $(\mu \mathrm{m})$} & 1544.1 & \pm 195.2 & 1118.3 & \pm 705.7 \\
\hline \multicolumn{2}{|c|}{ Fibers-tracheids diameter $(\mu \mathrm{m})$} & 28.6 & \pm 2.9 & 24.9 & \pm 3.2 \\
\hline \multicolumn{2}{|c|}{ Fibers-tracheids lumina $(\mu \mathrm{m})$} & 14.3 & \pm 1.6 & 11.8 & \pm 1.2 \\
\hline \multicolumn{2}{|c|}{ Fibers-tracheids wall thickeness $(\mu \mathrm{m})$} & 7.2 & \pm 0.7 & 6.5 & \pm 1.3 \\
\hline \multicolumn{2}{|c|}{ Fibers-tracheids pits $(\mu \mathrm{m})$} & 4.3 & \pm 1.2 & 3.8 & \pm 0.85 \\
\hline \multicolumn{2}{|l|}{ Gelatinous fibers } & present & & present & \\
\hline \multicolumn{2}{|c|}{ Rays frequency (linear mm) } & 3.0 & \pm 0.6 & 3.4 & \pm 0.1 \\
\hline \multicolumn{2}{|c|}{ Rays lenght $(\mu \mathrm{m})$} & 677.4 & \pm 112.4 & 746.5 & \pm 156.3 \\
\hline \multicolumn{2}{|c|}{ Rays width $(\mu \mathrm{m})$} & 80.6 & \pm 10.8 & 80.9 & \pm 3.3 \\
\hline \multicolumn{2}{|c|}{ Rays width (number of cells) } & $2-8$ & \pm 0.2 & $2-6$ & \pm 0.5 \\
\hline \multicolumn{2}{|l|}{ Sheath cells } & present & & present & \\
\hline \multicolumn{2}{|c|}{ Prismatic crystals } & present & & present & \\
\hline \multicolumn{2}{|c|}{ Indice of Vulnerability } & 0.5 & & 0.6 & \\
\hline \multicolumn{2}{|c|}{ Indice of Mesomorphy } & 401.0 & & 522.7 & \\
\hline
\end{tabular}

\section{RESULTS AND DISCUSSION}

In general, the examined qualitative characters were constant among all studied individuals of M. glabra from the two restinga formations (Table II), and were consistent with previously published data for the family Monimiaceae, subfamily Mollinedioideae, and the genus Mollinedia (Thorne 1974 apud Metcalfe 1987, Barros et al. 1997, Callado et al. 1997). This species demonstrates: diffuse porosity; vessel elements that are solitary, in radial groups, or clusters elements, being circular to angular in cross-section, with short appendices, perfo- ration plates with few bars (5-15), scalariform to opposite intervessel pitting and vessel-rays pitting predominantly scalariform; fiber-tracheids septate, ranging from thin to thick; axial parenchyma extremely rare; multiseriate rays wide (uniseriate rare), heterocellular, composed of procumbent cells in the central region and marginal rows of up right and square cells, with the presence of aggregated and fused rays, sheath cells and prismatic crystals (Figs. 2-4).

Species of Mollinedia previously studied at Rio de Janeiro State in an area of Dense Montane Ombrophilous Forest (Barros et al. 1997) demonstrated indistinct 
TABLE III

Student $t$ test results for parameters analyzed in both plant formations $(\alpha=\mathbf{0 , 0 5})$.

\begin{tabular}{l|c|c}
\hline Variables & $t$ (observed) & $\mathrm{p}$ \\
\hline VESSELS & & \\
Frequency $\mathrm{mm}^{2}$ & 4.39 & $<0.0001^{*}$ \\
Lenght & 0.37 & 0.7126 \\
Diameter & 1.63 & 0.1051 \\
Wall thickeness & -0.12 & 0.8997 \\
\hline FIBERS-TRACHEIDS & & \\
Lenght & 0.46 & 0.6452 \\
Diameter & 4.29 & $<0.0001^{*}$ \\
Lumina & 3.87 & $0.0001^{*}$ \\
Wall thickeness & 1.65 & 0.1008 \\
\hline RADIAL PARENCHYMA & & \\
Lenght & -2.52 & $0.0124^{*}$ \\
Width & -0.05 & 0.9577 \\
Number of cells & -0.92 & 0.3570 \\
Frequency linear mm & -2.26 & $0.0250^{*}$ \\
\hline
\end{tabular}

Values marked with $\left(^{*}\right)$ are statistically significant $(\mathrm{P}<0.05)$.

growth rings. In the studied specimens of M. glabra, the degrees of distinction of these rings ranged between the two different formations (Table II), with distinct layers marked by the thick-walled and radially flattened latewood fibers among individuals from the OPS (Fig. 2a).

The formation of growth rings in tropical species is usually associated with seasonal factors such as droughts, flooding, changes in the photoperiod, phenology, endogenous factors, or in response to stochastic factors such as insect attacks or diseases, the loss of branches, or other injuries (Worbes 1989, 1999, Alves and Angyalossy-Alfonso 2000, Callado et al. 2001, 2004). In the OPS area, the individuals of M. glabra experience frequent cutting and form latewood, laying down growth rings that probably represent responses to these injuries when they cease their radial growth due to the energetic investments required to form new branches. Another important characteristic of the individuals growing in the OPS is the presence of tyloses with sclerified walls (Fig. 3b). This characteristic can likewise be considered a response to anthropogenic disturbances in this formation. Tyloses are observed in some genera of the family Monimiaceae (Metcalfe 1987), although sclerification of these cells has not been mentioned previously in the literature. Carlquist (2001) considered the capacity to form sclerified tilos a valid taxonomic characteristic.

Among the examined quantitative characteristics, the two restinga formations only demonstrated significant differences in terms of the frequency of the vessel elements, the diameter of the lumen of the fibertracheids, and the length and the frequency of the rays (Table III). Numerous authors have noted that species growing in dry environments usually demonstrate increased frequencies of vessels with small diameters, associating conductive efficiency with conductive safety (Carlquist 1977, Baas et al. 1983). The individuals of M. glabra examined in the OPS area demonstrated a greater frequency of vessel elements than the one reported in SSCS individuals (Table II). In spite of this variation in their frequency, no significant statistical differences were observed in terms of the diameters of these elements (Tables II and III). Similar results for the variation of the frequency and diameter of vessel elements were found for the wood of Xilopia aromatica (Lam.) Mart. growing in cerrado (savanna) areas, and in plantations of Pinus elliottii Engelm (Luchi et al. 2005).

The higher frequency of vessel elements associated with fiber-tracheids that have increased diameters and lumens can be considered a structural adaptation related to the water requirements of plants growing in the OPS site, due to the greater exposure of these plants to direct sunlight. The fiber-tracheids in M. glabra are septate (Fig. 3c, d), which is a characteristic typical of the genus Mollinedia (Metcalfe 1987). Esau (2000) mentioned that, in taxa where axial parenchyma is extremely rare, as in the studied species, the septate fibers are responsible for the transport and storage of photosynthetic products.

Although statistical tests did not demonstrate significant differences in the lengths of the vessel elements between the two restinga formations, they did appear smaller in individuals from the OPS. This characteristic, together with the smaller numbers of bars on the perforation plates of the vessel elements (Fig. 2c, Table II), represents adaptations to drier environments (Wheeler and Baas 1991, Dickison 2000, Denardi and Marchiori 2005). Reductions in the numbers of bars per perforation plate in plants growing in xeric environments were 

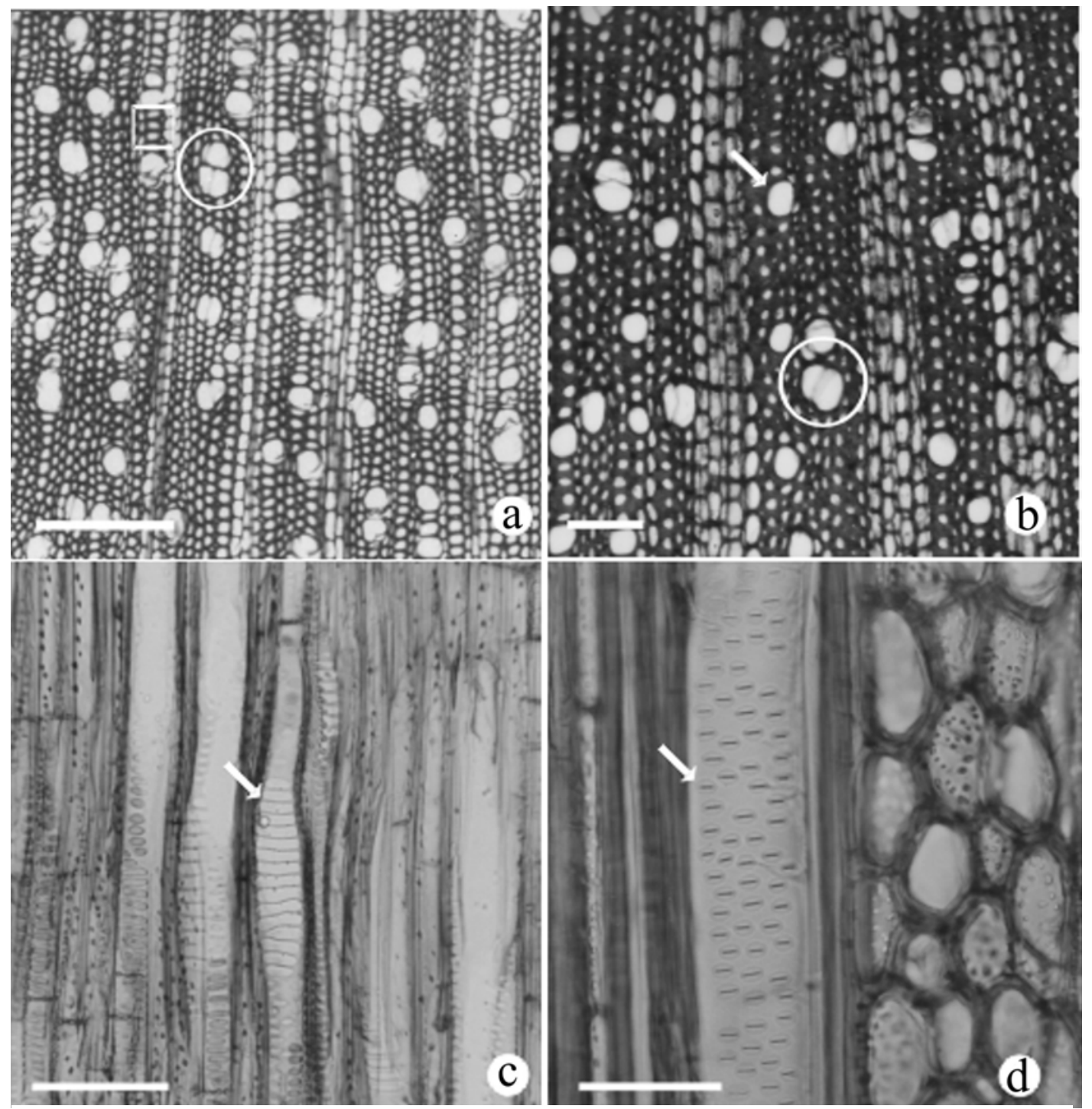

Fig. 2 - Cross and longitudinal sections of the branches of Mollinedia glabra. a. Growth rings distinct (square), difuse-porous, vessels clusters (circle) and solitary of OPS (CS). b. Growth rings indistinct or absent, difuseporous, vessels paired (circle) and solitary (arrow) of SSCS (CS). c. Scalariform plates (arrow) of OPS (RLS). d. Intervessel opposite (arrow) of OPS (TLS). Bar $=200 \mu \mathrm{m}(\mathrm{a}) ; 100 \mu \mathrm{m}(\mathrm{b}, \mathrm{c}) ; 50 \mu \mathrm{m}$ (d).

noted for M. glabra (5-15 bars) when compared to other species of Mollinedia growing in Dense Montane Ombrophilous Forests (and having from 20 to more than 40 bars) (Barros et al. 1997, Callado et al. 1997).

In spite of the placement of individuals of the two formations within the mesomorphic range (indices greater than 200), the results obtained in the present study corroborate the indices reported by Carlquist (1977) and indicate the presence of characteristics that are less mesomorphic and more vulnerable to xylem hydraulic conductivity in OPS individuals (Table II). Previous analyses undertaken with the species Mollinedia gilgiana Perkins, M. marliae A. Peixoto et V. Pereira, and M. salicifolia Perkins in Serra de Macaé de Cima (Callado et al. 1997) all demonstrated greater mesomorphic indices $(5,969,1,360$ and 6,740 , respectively) than those observed here with the specimens of M. glabra (401 and 522). 

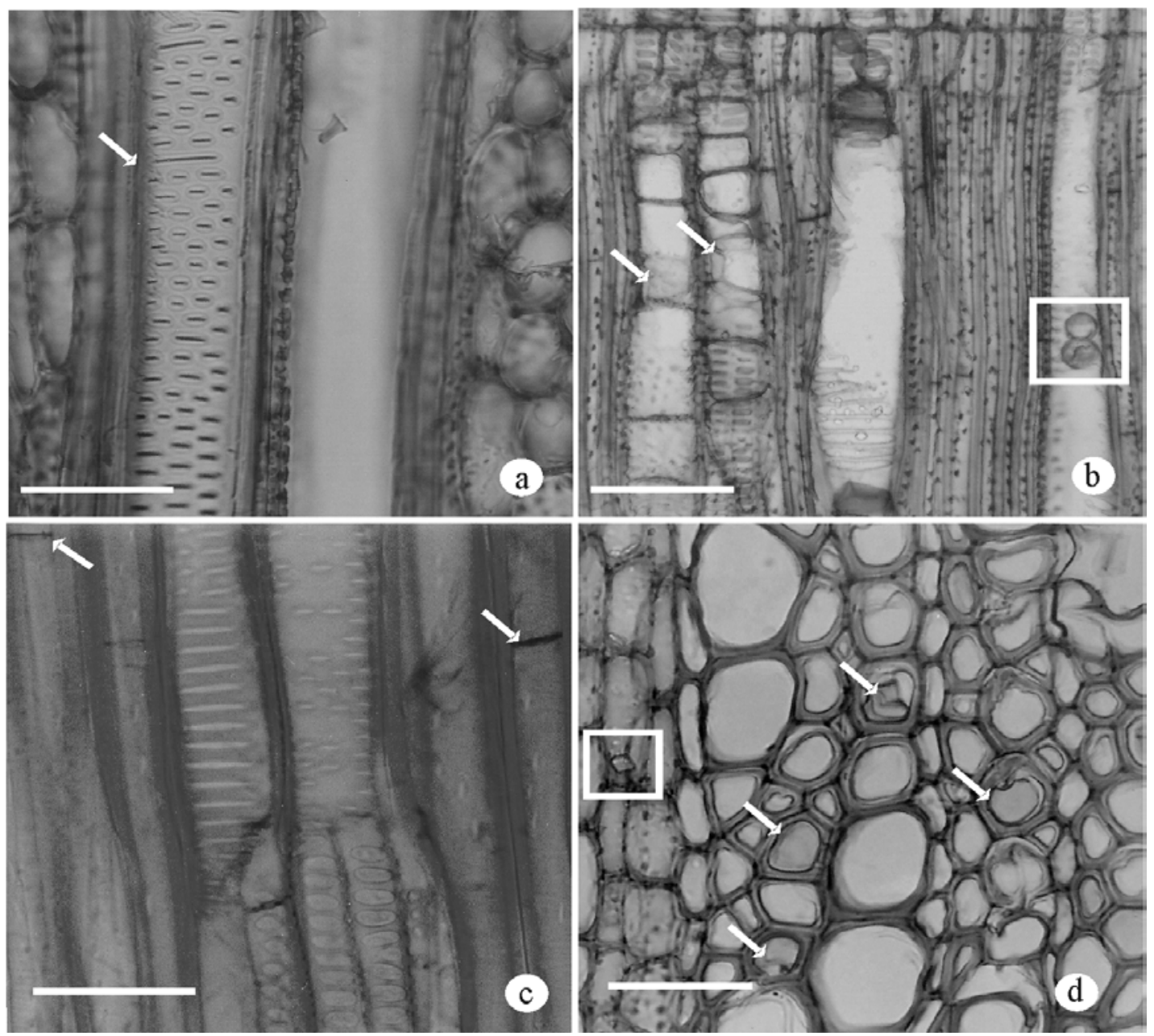

Fig. 3 - Mollinedia glabra wood. a. Details of intervessel pits scalariform to opposite (arrow) of OPS (TLS). b. Tyloses lightly sclerosed (arrows) and common tyloses (square) of OPS (RLS). c. Fiber-tracheids septate (arrows) of OPS (TLS). d. Fiber-tracheids (arrows) and presence of prismatic crystal (square) SSCS (CS). Bar $=50 \mu \mathrm{m}(\mathrm{a}, \mathrm{d}$ ); $100 \mu \mathrm{m}(\mathrm{b}, \mathrm{c})$.

The increase in the frequency and length of the rays among the species studied here may be associated with the increasing diameters of the branches among individuals in the SSCS site (Fig. 4). The greater height of the rays has been interpreted as being important for the efficiency of radial transport between the pith and the bark (Catesson 1990, Yáñez-Espinoza et al. 2001).

The results obtained in the present study demonstrated phenotypic variations in the wood of the species being studied, and pointed towards adaptations to micro-environmental variations during the development of plants growing in the restinga at Praia Virgem. The dioecious character of this species and the proximity of the individual plants favor the exchange of genetic ma- terial and argue for the existence of a single population of M. glabra in both vegetation formations.

\section{ACKNOWLEDGMENTS}

The authors would like to thank MSc. Henrique do Nascimento Braga for his help in locating the species and making the collections; MSc. Alexandre Gabriel Christo for performing the statistical analyses; the Laboratório de Botânica Estrutural of the Instituto de Pesquisas Jardim Botânico for logistical support; and the Fundação Carlos Chagas Filho de Amparo à Pesquisa no Estado do Rio de Janeiro (FAPERJ) for the grant awarded to the second author. To the anonymous reviewers, for their valuable comments. 

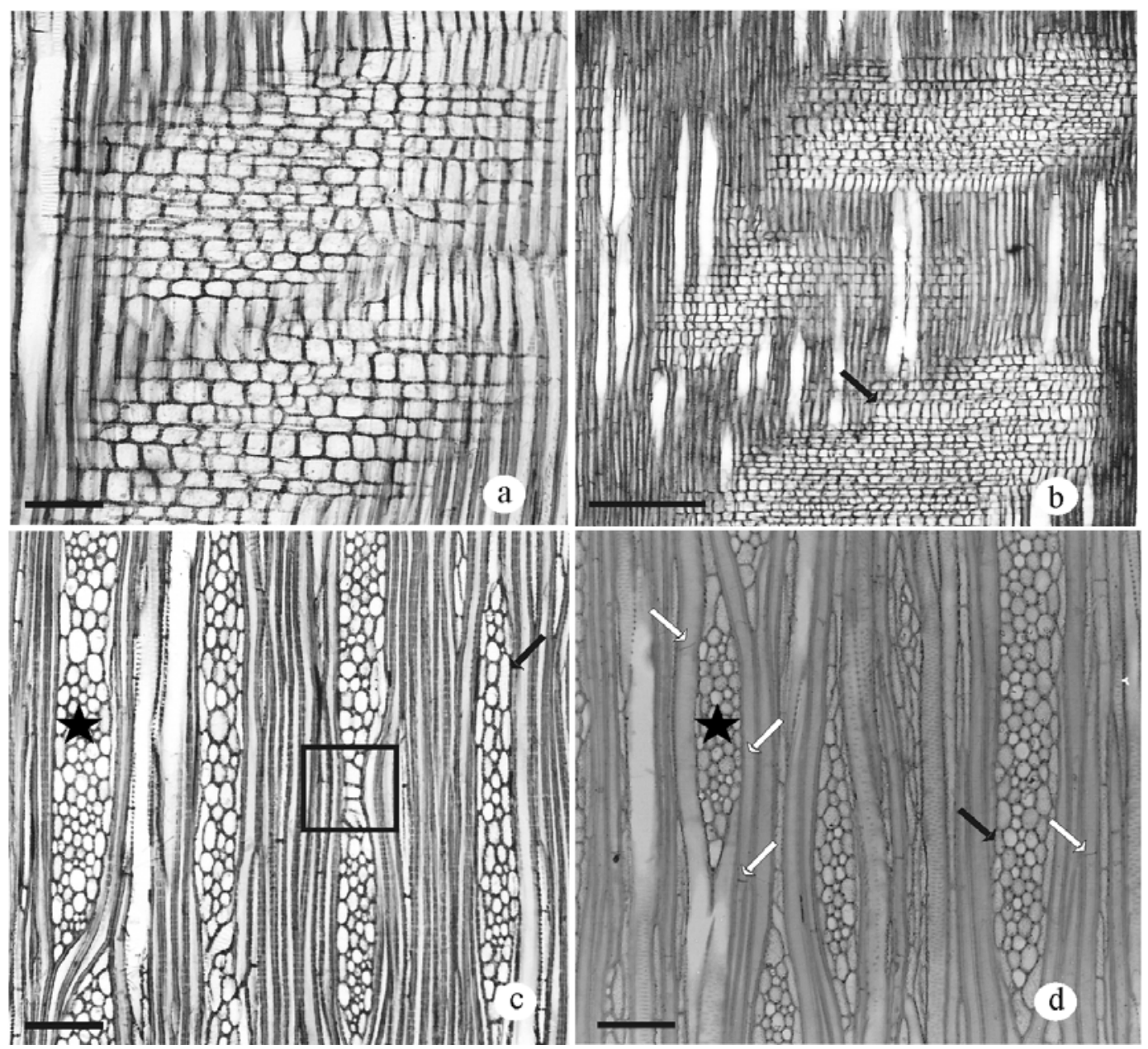

Fig. 4 - Longitudinal sections of branches of Mollinedia glabra. a. Upright cells, square and procumbent of OPS (RLS). b. Upright cells (arrow), square and procumbent of SSCS (RLS). c. Multisseriate rays ( $\star$ ), fusioned (square), sheath cells (arrow) of OPS (TLS). d. Multisseriate rays ( $\star$ ), sheath cells (black arrow); fiber-tracheids septate (white arrows) of SSCS (TLS). Bar $=100 \mu \mathrm{m}$ (a; c; d), $400 \mu \mathrm{m}(\mathrm{b})$.

\section{RESUMO}

Este trabalho objetiva caracterizar a estrutura anatômica do lenho de Mollinedia glabra, ocorrente em duas formações vegetais contíguas na restinga da Praia Virgem, município de Rio das Ostras, RJ. Essas formações Arbustiva Aberta de Palmae (AAP) e Arbustiva Fechada do Cordão Arenoso (AFCA) estão sobre cordão arenoso e recebem precipitações anuais de 1.100-1.300 mm. Foram obtidas amostras do lenho das duas formações. São características anatômicas gerais da espécie: elementos de vasos solitários, em arranjos radiais ou cachos, de seção de circular a angular; placa de perfuração escalariforme, com 5-15 barras; parênquima axial escasso; fibrotraqueídes septadas e raios multisseriados largos, com cristais prismáticos. A análise estatística evidenciou aumento significativo na frequência dos elementos de vasos e aumento no diâmetro das fibrotraqueídes nos indivíduos de AAP. Essas características são consideradas adaptações estruturais ao aumento da necessidade de água causada por maior exposição à luz solar. A realização de podas frequentes pode ter relação com a formação de tilos nesses indivíduos. O aumento significativo no comprimento e frequência de raios podem representar uma resposta ao maior diâmetro dos indivíduos em AFCA. Os resultados obtidos sugerem que M. glabra desenvolve adaptações estruturais às variações micro-ambientais da restinga durante seu desenvolvimento.

Palavras-chave: Mollinedia glabra, Monimiaceae, restinga, anatomia do lenho. 


\section{REFERENCES}

Aguilar-Rodríguez S AND BARAJAs-Morales J. 2005. Anatomía de la madera de especies arbóreas de un bosque mesófilo montaña: un enfoque ecológico-evolutivo. Bol Soc Bot Mex 77: 51-58.

Alves ES And Angyalossy-Alfonso V. 2000. Ecological trends in the anatomy of some Brazilian species. I: Growthrings and vessels. IAWA Journ 21: 3-30.

BAAS P. 1973. The wood anatomy of Ilex (Aqüifoliaceae) and its ecological and filogenetic. Significance. Blumea 21: $193-25$.

BAas P, Werker E ANd FAHn A. 1983. Some ecological trends in vessel characters. IAWA Bull 4: 141-159.

Barros CF, Callado CH, Costa CG, Pugialli HRL, Cunha M ANd Marquete O. 1997. In: BarRos CF AND CAllado CH (Orgs), Madeiras da Mata Atlântica-Anatomia do lenho de espécies ocorrentes nos remanescentes florestais do estado do Rio de Janeiro Brasil, Rio de Janeiro: JBRJ 1: 62-69.

Burguer LM AND Richter HG. 1991. Anatomia da Madeira. São Paulo: Ed Nobel, 154 p.

Callado CH, Pugialli HRl, Costa CG, Cunha M, Marquete O ANd Barros CF. 1997. Anatomia do lenho de espécies da Mata Atlântica: Interpretação ecológica e indicações para aproveitamento. In: LIMA HC And Guedes-Bruni RR (Eds), Serra de Macaé de Cima: Diversidade Florística e Conservação em Mata Atlântica, Rio de Janeiro: JBRJ, p. 251-273.

Callado CH, Silva Neto SJ, Scarano FR and Costa CG. 2001. Periodicity of growth rings in some floodprone trees of the Atlantic Rain Forest in Rio de Janeiro, Brazil. Trees - Structure and Function 15: 492-497.

Callado CH, Silva Neto SJ DA, Scarano FR and CostA CG. 2004. Radial growth dynamics of Tabebuia umbellata (Sond.) Sandwith (Bignoniaceae), a floodtolerant tree from the Atlantic Forest swamps in Brazil. IAWA J 25: 175-183.

CARLQuist S. 1975. Ecological strategies of xylem evolutions. Berkeley: University of California Press, 259 p.

CARLQUist S. 1977. Ecological factors in wood evolution: a floristic approach. Amer J Bot 64: 887-896.

CARlquist S. 2000. Wood and stem anatomy of Sarcobatus (Caryophyllales): systematic and ecological implications. Taxon 49: 27-34.

CARlquist S. 2001. Comparative wood anatomy. Berlin: Springer-Verlag, $448 \mathrm{p}$.
CATESSON AM. 1990. Cambial cytology and biochemistry. In: IQBAL M (Ed), The vascular cambium. London: Research Studies Press, p. 63-112.

CORADIN VTR AND MUÑIz GMB. 1991. Normas de procedimento em estudos de anatomia da madeira: I. Angiopermae. II Gimnospermae. L.P.F. 5: 1-19.

Denardi L AND MARChIORI JNC. 2005. Anatomia ecológica da madeira de Blepharocalyx salicifolius (H.B.K) Berg. Cienc Florest 15: 119-127.

DICKISON WC. 2000. Integrative Plant Anatomy. USA: Academic Press, 533 p.

EsaU K. 2000. Anatomia das plantas com sementes. São Paulo: Edgard Blucher.

FIDERJ. 1978. Indicadores climatológicos do estado do Rio de Janeiro. Governadoria do estado do Rio de Janeiro, Secretaria de Planejamento e Coordenação Geral (SECPLAN), Fundação Instituto de Desenvolvimento Econômico e Social do Rio de Janeiro (FIDERJ). Sistemas de Informação para o Planejamento Estadual (SIPE), 156 p.

IBAMA (Instituto BRAsileiro do Meio AMBIENTE E Dos ReCURSOS NATURAis RENOVÁveis). 2008. Instrução Normativa, setembro, (www.ibama.gov.br/sisbio/ legislacao.php?id_arq=42), (acesso em 15/01/2009).

IAWA COMMITTEE. 1989. List of microscopic features for hardwood identification. IAWA Bull 10: 219-332.

Leitão GG, Simas NK, SoAres SSV, Brito APP, Claros BMG, Brito TBM And Monache FD. 1999. Chemistry and pharmacology of Mominiaceae: a special focus on Siparuna and Mollinedia. J Ethnopharmacol 65: 87-102.

LEÓN HWJ. 2005. Anatomía ecológica del xilema secundario de um bosque seco tropical de Venezuela. Acta Bot Venez 28: 257-274.

LILLIEFORS H. 1967. On the Kolmogorov-Smirnov test for normality with mean and variance unknown. J Amer Statistical Assoc 62: 399-402.

Luchi AE, Silva LC And Moraes MA. 2005. Anatomia comparada do lenho de Xylopia aromatica (Lam.) Mart. em áreas de cerrado e de plantação de Pinus elliottii Engelm. Revista Brasil Bot 28: 809-820.

Marcati CR, Angyalossy-Alfonso V AND BeRneTATI L. 2001. Anatomia comparada do lenho de Copaifera langsdorffii Desf. (Leguminosae-Caesalpinoideae) de floresta e cerradão. Revista Brasil Bot 3: 311-320.

Menezes LFT, Peixoto AL and Araujo DSD. 2005. Aspectos Florísticos e Vegetacionais da Marambaia, Rio de Janeiro, Brasil. In: PEIXOTO AL AND ARAUJo DSD 
(Eds), História Natural da Marambaia, Seropédica: Edur, p. $67-120$.

MetCAlfe CR. 1987. Anatomy of the Dicotyledons. Oxford: Clarendon. Press, 297 p.

MetCalfe CR. 1989. Anatomy, Phylogeny and Taxonomy. In: Metcalfe CR AND CHALK L (Eds), Anatomy of the Dicotyledons. Wood Structure and Conclusion of the General Introduction, Oxford: University Press, p. 108-125.

OCChioni P. 1948. Histologia e Anatomia dos órgãos vegetais (raiz, caule, folha e fruto). Contribuição do estudo da família Canellaceae. Arq Jard Bot 8: 3-96.

Peixoto L, Santos is and Pereira-Moura MVL. 2002. Monimiaceae. In: WANDERLEy MGL, SHEPHERd GJ AND GiUlietti AM (Coords), Flora fanerogâmica do estado de São Paulo, São Paulo: Fapesp/ Editora HUCITEC 2: 189-207.

Peixoto L And Pereira-Moura MVL. 2008. A new genus of Monimiaceae from the Atlantic Coastal Forest in Southeastern Brazil. Kew Bull 63: 137-141.

PeiXoto LA. 1979. Contribuição ao conhecimento da seção Exppendiculatae Perkins do gênero Mollinedia Ruiz et Pavon (Mollinedia, Monimoideae, Monimiaceae). Rodriguésia 31: 135-222.
Peixoto LA, Reitz R And Guimarães FE. 2001. Monimiáceas. Flora Ilustrada Catarinense. Parte 1, 63 p.

Ribeiro MLR DA C AND BARRos CF. 2006. Variação intraspecífica do lenho de Pseudopiptadenia contorta (DC.). Lewis GP and Lima MP (Leguminosae-Mimosoideae) de populações ocorrentes em dois remanescentes de Floresta Atlântica. Acta Bot Bras 20: 839-844.

WheEler EA AND BAAS P. 1991. A survey of the fossil record for dicotyledonous wood and its significance for evolutionary and ecological wood anatomy. IAWA Bull 12: 275-332.

Worbes M. 1989. Growth rings, increment and age of trees in inundation forests, savannas and a mountain forest in the neotropics. IAWA Bull 10: 109-122.

Worbes M. 1999. Annual growth rings, rainfall-dependent growth and long-term growth patterns of tropical trees from the Caparo Forest Reserve in Venezuela. J Ecol 87: 391-403.

YÁÑEZ-EsPinosa L, TERRAZAs T AND López-MATA L. 2001. Effects of flooding on wood and bark anatomy of four species in a mangrove forest community. Trees 15 : 91-97. 